\title{
Is There a Relationship Between Ovarian Reserve Tests with Depression and Anxiety Scales?
}

\author{
Over Rezerv Testleri ile \\ Depresyon ve Anksiyete Ölçekleri Arasında İlişki Var mı?
}

\section{S. Özlem ALTINKAYA, ${ }^{a}$ Sümeyra NERGIZ AVCIOĞLU, Mert KÜÇÜK, Hasan YÜKSEL ${ }^{a}$}

${ }^{a}$ Department of Obstetrics and Gynecology, Adnan Menderes University

Faculty of Medicine, Aydın bDepartment of Obstetrics and Gynecology, Muğla Sıtkı Koçman University

Faculty of Medicine, Muğla

Geliş Tarihi/Received: 26.10 .2016

Kabul Tarihi/Accepted: 16.02.2017

Yazışma Adresi/Correspondence:

S. Özlem ALTINKAYA

Adnan Menderes University

Faculty of Medicine,

Department of Obstetrics and Gynecology,

Aydın,

TURKEY/TÜRKIYE

altinkayaozlem@yahoo.com

This study was presented in part as oral presentation at $X^{\text {th }}$ Turkish German Gynecologic Congress, 11-15 May 2016, Antalya, Turkey.

\begin{abstract}
Objective: An important point at issue has been shown by the possible causal connection between psychopathology and infertility. The aim of the present study was to investigate whether there was an association between ovarian reserve tests and depression and anxiety scales. Material and Methods: A total of 50 women, who attended the infertility clinic of Adnan Menderes University Hospital, with primary infertility, were eligible for the study. Anti-mullerian hormone $(\mathrm{AMH})$, follicle stimulating hormone, luteinizing hormone and estradiol levels were assessed for establishing ovarian reserve. All participants fulfilled standardized questionnaires evaluating depression Beck Depression Inventory (BDI) and anxiety Beck Anxiety Inventory (BAI). Multiple Linear Regression analyses were used to determine the best independent predictor(s) which affected on both BDI and BAI levels. Results: Both depression and anxiety scores were positively correlated with age, body mass index (BMI), duration of infertility, and diminished ovarian reserve $(p<0.05)$. Regression analyses showed that lower AMH levels $(\mathrm{p}<0.001)$, higher BMI $(\mathrm{p}<0.05)$ and longer duration of infertility $(\mathrm{p}<0.05)$ were the predictors of both higher depression and anxiety scores. Conclusion: The data of the present study have established that higher depression and anxiety scores were associated with poor ovarian reserve as well as higher BMI and longer duration of infertility, suggesting that psychological support is needed for this group of women.
\end{abstract}

Keywords: Infertility; depression; anxiety

ÖZET Amaç: İnfertilite ile psikopatoloji arasında önemli bağlantı olduğu düşünülmektedir. Bu çalışmanın amacı infertil hastalarda depresyon ve anksiyeteyi ölçekler vasıtasıyla değerlendirip bu ölçeklerin over rezerv testleriyle ilişkisini araştırmaktır. Gereç ve Yöntemler: Çalışmaya infertilite şikayeti ile başvuran 50 primer infertil hasta dahil edildi. Over rezervinin değerlendirilmesi amacıyla anti-müllerian hormon (AMH), siklusun 2-3-4'üncü günlerinde folikül stimülan hormon (FSH), lüteinizan hormon (LH), östradiol (E2) düzeyleri çalışıldı. Beck depresyon (BDI) ve Beck anksiyete (BAI) ölçekleri anket yöntemiyle doldurtuldu. Çoklu lineer regresyon analizleri ile bu ölçeklere etki eden en iyi bağımsız prediktörler tespit edildi. Bulgular: Hem depresyon hem de anksiyete skorları yaş, beden kitle indeksi (BKİ), infertilite süresi ve azalmıș over rezervi ile pozitif korelasyon gösterdi $(\mathrm{p}<0,05)$. Regresyon analizi sonuçlarına göre düşük $A M H$ düzeyleri $(\mathrm{p}<0,001)$, yüksek BKİ $(p<0,05)$ ve infertilite süresinin uzunluğu $(p<0,05)$ yüksek anksiyete ve depresyon skorları için en iyi prediktörler olarak belirlendi. Sonuç: Bu çalışmanın sonuçlarına göre yüksek anksiyete ve depresyon skorları düşük over rezervi, yüksek BKİ ve infertilite süresinin uzunluğu ile ilişkilidir. Klinisyenler, infertil hastaların anksiyete ve duygu durum bozuklukları için yüksek risk grubunda oldukları konusunda bilinçli olmalıdır ve bu grup hastalara gerekli psikolojik destek sağlanmalıdır.

Anahtar Kelimeler: İnfertilite; depresyon; anksiyete $\mathrm{n}$ important mood point has been shown by the possible causal connection between psychopathology and infertility. The adverse effect of infertility on the psychological wellbeing of women has 
attracted increasing notice in a lot of researches. Infertile women report higher levels of emotional distress and psychological stress than fertile controls. ${ }^{1-3}$ In addition, a considerable proportion of infertile women show substantial emotional problems, mood and anxiety disorders, and low quality of life. ${ }^{4-7}$ The prevalence of psychiatric trouble in infertile couples was notified to be 25$60 \%{ }^{8}$

Fertility has always been closely in association with aging in women. The age of the infertile women still remains the single most important predictor of success with treatment. Ovarian reserve tests provide an indirect estimate of a woman's remaining follicular pool. The primary goal of ovarian reserve testing is to identify women at risk of decreased or diminished ovarian reserve, with a secondary goal of individualizing treatment strategies for each woman ${ }^{9}$. Ovarian reserve tests include basal follicle stimulating hormone (FSH), estradiol (E2), inhibin-B, antimullerian hormone (AMH) assessments, antral follicle count, ovarian volume measure as well as clomiphene citrate challenge test. Although these tests may predict ovarian response to infertility treatment, they do not reliably predict failure to conceive. $^{9}$

Up until this time, research has been made on associations between endogenous hormones and depressive mood in postmenopausal or premenopausal woman in relation with ovarian aging. ${ }^{10-12}$ However, there are no data investigating the relationship between ovarian reserve tests and mood and anxiety disorders in infertile women. In the present study we aimed to investigate whether there was an association between ovarian reserve tests and depression and anxiety scales in infertile women. Moreover this study also set out to determine the predictors of higher depression and anxiety scores in infertile women.

\section{MATERIAL AND METHODS}

Ethical Committee and Institutional Review Board approval was obtained from Adnan Menderes Uni- versity Faculty of Medicine. Written informed consents were taken from all participants.

The present study was designed as a cross-sectional study. The study compromised 50 women, who attended to our gynecology outpatient clinic between July 2015 and December 2015 with primary infertility. Eight women denied attending the survey. They self-completed the questionnaires. The women with a history of psychiatric diseases and/or systemic diseases were not included. Subjects taking any medication for at least three months prior to the study were also excluded. Detailed clinical history was questioned and physical examination was performed for all subjects. None of the patients experienced any kind of infertility treatment before. Body mass index (BMI) was also calculated. Laboratory investigations included luteinizing hormone (LH), FSH, E2 levels. These sampling sera were obtained in the early follicular phase (on day 2-4 of the menstrual cycle). AMH levels were assessed by enzyme-linked immunosorbent assay (AMH Gene II ELISA, Beckman Coulter, Brea, USA). The lowest detection limit was 0.08 $\mathrm{ng} / \mathrm{ml}$, with a probability of $95 \%$. AMH levels were detected at any day of the menstrual cycle as it does not exhibit intercycle variability. ${ }^{9}$

All women answered the Beck Depression Inventory (BDI) and Beck Anxiety Inventory (BAI). BDI, which is created by Dr. Beck, includes 21 questions. ${ }^{13}$ It is a multiple choice self report inventory for evaluating the severity of depression. The most current version of the questionnaire consists of items relating to depression symptoms. ${ }^{13}$ These symptoms include irritability, hopelessness, and cognitions such as guilt or feelings of being punished, in addition to physical symptoms such as weight loss, fatigue, and lack of interest in sex..$^{13}$ The BDI has a maximum score of 63 (0-9: shows minimal depression, 10-16: shows mild depression, 17-29: shows moderate depression, 30-63: shows severe depression). ${ }^{13}$ Similarly BAI, also created by Dr. Beck, is composed of 21 -questions. ${ }^{14}$ This questionnaire is a multiple-choice self-report inventory too. It is used for evaluating the severity of an individual's anxiety. ${ }^{14}$ These questions are about how the subject has been feeling in the last month, sig- 
nified as common symptoms of anxiety such as tingling numbness, sweating, and fear for the worst happening. ${ }^{14}$ The BAI has a maximum score of 63. (0-7: minimal level of anxiety 8-15: mild anxiety 16-25: moderate anxiety 26-63: severe anxiety). ${ }^{14}$

Data analysis was performed by using SPSS for Windows, version 18 . Whether the metric discrete and continuous variables were normally distributed or not were controlled by Shapiro Wilk test. Metric discrete and continuous variables were shown as mean \pm standard deviation or median (min-max), where applicable. The differences in median values between groups were compared by Mann Whitney U test. Degrees of association between variables were calculated by Spearman correlation analyses. Multiple Linear Regression analyses were used to determine the best independent predictor(s) which affected on both BDI and BAI levels. Coefficient of regression and 95\% confidence intervals for each independent variable were also calculated. Logarithmic transformations were applied for BDI and BAI in linear regression analyses because of the not normally distributed. $\mathrm{P}$ values $<0.05$ was considered statistically significant.

\section{RESULTS}

A total of 50 women with primary infertility participated in this study and completed the questionnaires. Demographic, clinical, psychological characteristics of the participants are summarized in Table 1. There was no patient with severe depression scores however, 9 (18\%) women had scores $\geq 17$ on the BDI indicating moderate depression that needs to be treated. Thirty-five (70\%) women had minimal and 6 (12\%) women had moderate BDI scores. Similarly, there was no patient with severe anxiety scores, however, 11 (22\%) showed moderate BAI scores, whereas 11 (22\%) women showed mildand 28 (56\%) showed minimal anxiety scores. In the study population 42 (84\%) women were housewives and 8 (16\%) were working. No significant difference was found in BDI and BAI scores of housewives and employees (Table 2).

Correlation analyses showed that age was positively correlated with BMI $(\mathrm{p}<0.001$,
TABLE 1: Demographic, clinical and psychological characteristics of the participants.

\begin{tabular}{|lc|}
\hline Characteristics & $\mathrm{n}=50$ \\
Age (years) & $27.8 \pm 5.0$ \\
Duration of infertility (months) & $29(12-96)$ \\
Employee & $8(16.0 \%)$ \\
BMl (kg/m2) & $26.2 \pm 4.7$ \\
FSH & $4.8(1.7-32.0)$ \\
LH & $5.7(1.4-49.0)$ \\
E2 & $47.0(13.0-131.0)$ \\
AMH & $3.3(0.1-17.6)$ \\
BDI & $7.5(2.0-21.0)$ \\
BAI & $7.0(4.0-20.0)$ \\
\hline
\end{tabular}

BMI: body mass index, FSH: follicle stimulating hormone, $\mathrm{LH}$ : luteinizing hormone, E2:estradiol, AMH: anti-mullerian hormone, BDI: Beck Depression Inventory, BAl: Beck Anxiety Inventory

TABLE 2: Depression and anxiety scores for housewives and employees.

\begin{tabular}{|lccc|}
\hline Scores & Housewives $(n=42)$ & Employee $(n=8)$ & $p$ \\
BDI & $7(2-21)$ & $8(4-18)$ & 0.507 \\
BAl & $7(4-20)$ & $7(4-17)$ & 0.594 \\
\hline
\end{tabular}

BDI: Beck Depression Inventory, BAl: Beck Anxiety Inventory

$\mathrm{r}=0.491)$, duration of infertility $(\mathrm{p}<0.001$, $\mathrm{r}=0.569)$, and FSH levels $(\mathrm{p}=0.038, \mathrm{r}=0.295)$ and negatively correlated with AMH levels $(\mathrm{p}<0.001$, $\mathrm{r}=-0.486$ ). Table 3 shows the significant correlations between depression/anxiety scores and clinical characteristics as well as ovarian reserve tests. Both BDI and BAI were positively correlated with age, $\mathrm{BMI}$ and duration of infertility and FSH levels and were in negative correlation with AMH levels.

Multiple Linear Regression analyses showed that $\mathrm{AMH}$ levels, BMI and the duration of infertility were the best independent predictors that affected on both BDI and BAI. Table 4 shows the coefficient of regression and $95 \%$ confidence intervals for each independent variable.

\section{DISCUSSION}

The data of the present study have established that higher depression and anxiety scores were associated with poor ovarian reserve. In addition, these 


\begin{tabular}{|c|c|c|c|c|}
\hline \multicolumn{5}{|c|}{$\begin{array}{c}\text { TABLE 3: Correlations between depression/anxiety } \\
\text { scores and clinical characteristics and ovarian } \\
\text { reserve tests. }\end{array}$} \\
\hline & \multicolumn{2}{|c|}{ BDI } & \multicolumn{2}{|c|}{ BAI } \\
\hline & $r$ & $p$ & $r$ & $p$ \\
\hline Age & 0,492 & $<0,001$ & 0,527 & $<0,001$ \\
\hline Duration of infertility & 0,802 & $<0,001$ & 0,821 & $<0,001$ \\
\hline $\mathrm{BMl}(\mathrm{kg} / \mathrm{m} 2)$ & 0,598 & $<0,001$ & 0,587 & $<0,001$ \\
\hline FSH & 0,454 & $<0,001$ & 0,403 & 0,004 \\
\hline $\mathrm{LH}$ & $-0,130$ & 0,369 & $-0,194$ & 0,176 \\
\hline E2 & 0,258 & 0,070 & 0,253 & 0,076 \\
\hline $\mathrm{AMH}$ & $-0,950$ & $<0,001$ & $-0,935$ & $<0,001$ \\
\hline
\end{tabular}

BMl: body mass index, FSH: follicle stimulating hormone, LH: luteinizing hormone, E2:estradiol, AMH: anti-mullerian hormone, BDI: Beck Depression Inventory, BAI: Beck Anxiety Inventory

scores were in correlation with higher BMI and longer duration of infertility, suggesting that psychological support is needed for this group of women.

To date, many researches showed that depression and anxiety were more frequently observed in women with infertility as compared to controls. ${ }^{1-6}$ Matsubayashi et al. reported that both scores were significantly higher in infertile women than those of pregnant women, and scores were not affected by women's work state similar to our data, however, their scores were not affected by age and duration of infertility in contrast with our data. ${ }^{1}$ In another study infertile women were reported to have higher scores of suspicion, guilt and hostility. ${ }^{2}$ In addition these women had higher levels of prolactin and cortisol throughout the menstrual cycle showing higher stress levels. Klemetti et al. mentioned that infertility was associated with mental health as the childless infertile women had intensified adjusted risk for anxiety disorders. ${ }^{3}$ Chen at al. conducted a study on 112 participants in an assisted reproductive technique clinic. ${ }^{5}$ Their results mentioned that $40.2 \%$ of the participants had a psychiatric disorder. The most common diagnosis was reported to be generalized anxiety disorder followed by major depressive disorder in their study. However, their results showed that participants with a psychiatric morbidity did not differ from those without in terms of age, education, income and years of infertility. Ramezanzadeh et al. also investigated depression and anxiety scores in infertile women population. ${ }^{6}$ They reported noteworthy increased levels of depression and anxiety;

\begin{tabular}{|c|c|c|c|c|}
\hline \multirow[t]{2}{*}{ Variables } & \multirow[t]{2}{*}{ Coefficient of regression } & \multicolumn{2}{|c|}{$95 \%$ Confidence Interval } & \multirow[t]{2}{*}{$\mathrm{p}$} \\
\hline & & Minimum & Maximum & \\
\hline \multicolumn{5}{|l|}{$\mathrm{BDI}$} \\
\hline Age & 0,004 & $-0,013$ & 0,021 & 0,648 \\
\hline BMI & 0,027 & 0,008 & 0,045 & 0,005 \\
\hline Duration of infertility & 0,007 & 0,002 & 0,012 & 0,008 \\
\hline FSH & 0,012 & $-0,003$ & 0,027 & 0,124 \\
\hline E2 & 0,002 & $-0,001$ & 0,005 & 0,167 \\
\hline $\mathrm{AMH}$ & $-0,078$ & $-0,098$ & $-0,058$ & $<0,001$ \\
\hline \multicolumn{5}{|l|}{ BAI } \\
\hline Age & 0,009 & $-0,009$ & 0,026 & 0,321 \\
\hline BMI & 0,026 & 0,007 & 0,045 & 0,008 \\
\hline Duration of infertility & 0,006 & 0,001 & 0,012 & 0,018 \\
\hline FSH & 0,015 & $-0,0004$ & 0,030 & 0,056 \\
\hline E2 & 0,002 & $-0,001$ & 0,005 & 0,115 \\
\hline $\mathrm{AMH}$ & $-0,059$ & $-0,080$ & $-0,039$ & $<0,001$ \\
\hline
\end{tabular}

BMI: body mass index, FSH: follicle stimulating hormone, LH: luteinizing hormone, E2:estradiol, AMH: anti-mullerian hormone, BDI: Beck Depression Inventory, BAl: Beck Anxiety Inventory 
$40.8 \%$ women had depression and $86.8 \%$ women had anxiety. Depression was in relation with cause of infertility, duration of infertility, educational level and job of women whereas anxiety was associated with only duration of infertility and educational level. These high levels may be because of religious and cultural reasons as in some Islamic and eastern countries in which second marriage for men to marry with more than one woman, family status especially childbearing is very important and valuable. Although this study was carried out in only infertile population without a control group our data reported similar scores to the western countries. These results may be attributed to the fact that the study was conducted in the western region of the country or to the Turkish legislation law similar to western countries although the population was Muslim.

Up until this time, research has been made on associations between endogenous hormones and depressive mood in postmenopausal or premenopausal woman in relation with ovarian aging. ${ }^{10-12}$ However, there are no data investigating the relationship between ovarian reserve tests and mood and anxiety disorders in infertile women. Fertility and age have always had intimate relationship and the age of the female partner still remains the single most important success factor in predicting the result of treatment. ${ }^{15}$ According to the results of the present study we suggest that the depression and anxiety scales increased due to the clinical information about ovarian reserve and the possibility of poor ovarian response to infertility treatment, but not because of the effects of endogenous hormones in the way that premenopausal women have. We did not include premenopausal women in this study. The mean age is 27.8 years. Currently, there is no uniformly accepted definition of decreased ovarian reserve. However, decreased or diminished ovarian reserve describes women of reproductive age having regular menses whose response to ovarian stimulation or fecundity is reduced compared with women of comparable age. Decreased ovarian reserve is distinct from menopause or premature ovarian failure (also referred to as primary ovarian insufficiency). ${ }^{16}$ However, when test results suggest decreased or di- minished ovarian reserve, it is reasonable to counsel the woman that her window of opportunity to conceive may be shorter than anticipated and attempting to conceive sooner rather than later is encouraged.

Because the inter and intra cycle variability of $\mathrm{AMH}$ is low enough to assess at any time of the cycle we detected AMH levels in each patient on the day the questionnaires were filled out. FSH and E2 levels were the values belonging to the same cycle on day 2-4. AMH together with antral follicle count are considered the best predictors of the ovarian reserve. ${ }^{9-15}$ But we could not evaluate antral follicle count since we could not examine all patients by ultrasonography in the early follicular phase. One study investigated psychological factors in relation to antral follicle count, which is an important marker of ovarian reserve, in 683 premenopausal women in Ovarian Aging Study. ${ }^{17}$ Their results suggested that there are negative effects of psychological stress on antral follicle count, thus on ovarian reserve. Nevertheless, to the best of our knowledge the present study is the first one investigating whether there was an association between ovarian reserve tests and depression and anxiety scales in infertile women. Moreover this study also set out to determine the predictors of higher depression and anxiety scores in infertile women. We declared a strong association with ovarian reserve tests and depression/anxiety scales in our study. Additionally our results suggested that AMH levels, BMI and longer duration of infertility were the best predictors affecting these scores, as expected. Higher BMI was also demonstrated to associate with psychiatric disorders and co-morbidity in various studies. ${ }^{17-19}$

However, there are some limitations of the present study. One of the limitations of the present study was the small sample size. Moreover, the diagnoses were made by questionnaires without clinical interviews performed by physicians specialized in psychiatry which may constitute potential bias of self report assessment tools.

Taken together, the data of the present study have suggested that higher depression and anxiety 
scores were associated with poor ovarian reserve as well as higher BMI and longer duration of infertility, suggesting that psychological support is needed for this group of women.

\section{Conflict of Interest}

Authors declared no conflict of interest or financial support.

\section{Authorship Contributions}

Protocol/project development-Data collection and management-Data analysis-Manuscript writing/editing: $S$. Özlem Altınkaya; Data collection and management: Sümeyra Nergiz Avcıoğlu; Protocol/project development: Mert Küçük: Manuscript editing, consultantship: Hasan Yüksel.
1. Matsubayashi H, Hosaka T, Izumi S, Suzuki $\mathrm{T}$, Makino T. Emotional distress of infertile women in Japan. Hum Reprod 2001;16(5): 966-9.

2. Csemiczky G, Landgren BM, Collins A. The influence of stress and state anxiety on the outcome of IVF treatment: psychological and endocrinological assessment of Swedish women entering IVF-treatment. Acta Obstet Gynecol Scand 2000;79(2):113-8.

3. Klemetti R, Raitanen J, Sihvo S, Saarni S, Koponen $P$. Infertility, mental disorders and wellbeing--a nationwide survey. Acta Obstet Gynecol Scand 2010;89(5):677-82.

4. Verhaak CM, Smeenk JM, van Minnen A, Kremer JA, Kraaimaat FW. A longitudinal, prospective study on emotional adjustment before, during and after consecutive fertility treatment cycles. Hum Reprod 2005;20(8): 2253-60.

5. Chen TH, Chang SP, Tsai CF, Juang KD. Prevalence of depressive and anxiety disorders in an assisted reproductive technique clinic. Hum Reprod 2004;19(10): 2313-8.

6. Ramezanzadeh F, Aghssa MM, Abedinia N, Zayeri F, Khanafshar N, Shariat M, et al. A survey of relationship between anxiety, depression and duration of infertility. BMC Womens Health 2004;4(1):9.

\section{REFERENCES}

7. Aarts JW, van Empel IW, Boivin J, Nelen WL, Kremer JA, Verhaak CM. Relationship between quality of life and distress in infertility: a validation study of the Dutch FertiQoL. Hum Reprod 2011;26(5):1112-8.

8. De Berardis D, Mazza M, Marini S, Del Nibletto L, Serroni N, Pino MC, et al. Psychopathology, emotional aspects and psychological counselling in infertility: a review. Clin Ter 2014;165(3):163-9.

9. Committee on Gynecologic Practice. Committee opinion no. 618: Ovarian reserve testing. Obstet Gynecol 2015;125(1):268-73.

10. Ryan J, Burger HG, Szoeke C, Lehert $P$, Ancelin ML, Henderson VW, et al. A prospective study of the association between endogenous hormones and depressive symptoms in postmenopausal women. Menopause 2009;16(3): 509-17.

11. Schmidt PJ, Murphy JH, Haq N, Danaceau MA, St Clair L. Basal plasma hormone levels in depressed perimenopausal women. Psychoneuroendocrinology 2002;27(8):907-20.

12. Freeman EW, Sammel MD, Lin H, Nelson DB. Associations of hormones and menopausal status with depressed mood in women with no history of depression. Arch Gen Psychiatry 2006;63(4):375-82.

13. Beck AT, Ward CH, Mendelson M, Mock J, Erbaugh J. An inventory for measuring de- pression. Arch Gen Psychiatry 1961;4:56171.

14. Beck AT, Epstein N, Brown G, Steer RA. An inventory for measuring clinical anxiety: psychometric properties. J Consult Clin Psychol 1988;56(6):893-7.

15. George K, Kamath MS. Fertility and age. J Hum Reprod Sci 2010;3(3):121-3.

16. Practice Committee of the American Society for Reproductive Medicine. Testing and interpreting measures of ovarian reserve: a committee opinion. Fertil Steril 2015;103(3):e9-e17.

17. Bleil ME, Adler NE, Pasch LA, Sternfeld B, Gregorich SE, Rosen MP, et al. Depressive symptomatology, psychological stress, and ovarian reserve: a role for psychological factors in ovarian aging? Menopause 2012; 19(11):1176-85.

18. Petry NM, Barry D, Pietrzak RH, Wagner JA Overweight and obesity are associated with psychiatric disorders: results from the National Epidemiologic Survey on Alcohol and Related Conditions. Psychosom Med 2008;70(3):28897.

19. Guedes EP, Madeira E, Mafort TT, Madeira M, Moreira RO, Mendonça LM, et al. Body composition and depressive/anxiety symptoms in overweight and obese individuals with metabolic syndrome. Diabetol Metab Syndr 2013;5(1):82. 